Article

\title{
Identification and Quantification of Transient Receptor Potential Vanilloid 1 (TRPV1) in Equine Articular Tissue
}

\author{
Anne Frank Gallagher vom Braucke ${ }^{1}$, Nanna Lysemose Frederiksen ${ }^{1}$, Lise Charlotte Berg ${ }^{1}(\mathbb{D}$, \\ Stacie Aarsvold ${ }^{2}$, Felix Christoph Müller ${ }^{3}\left[\right.$, Mikael Ploug Boesen ${ }^{4}$ and Casper Lindegaard $1, * \mathbb{C}$ \\ 1 Large Animal Teaching Hospital, Department of Veterinary Clinical Sciences, Faculty of Health and Medical \\ Sciences, University of Copenhagen, DK-2630 Taastrup, Denmark; rpw642@alumni.ku.dk (A.F.G.v.B.); \\ djf458@alumni.ku.dk (N.L.F.); lcb@sund.ku.dk (L.C.B.) \\ 2 Puchalski Equine Imaging, CA, Petaluma, CA 94954, USA; saarsvolddvm@gmail.com \\ 3 Department of Radiology, Herlev and Gentofte Hospital, DK-2730 Herlev, Denmark; \\ christoph.felix.mueller@regionh.dk \\ 4 Department of Radiology, Copenhagen University Hospital Bispebjerg and Frederiksberg, \\ DK-2400 Copenhagen, Denmark; Mikael.ploug.boesen@regionh.dk \\ * Correspondence: casper.lindegaard@sund.ku.dk; Tel.: +45-93509135
}

Received: 10 February 2020; Accepted: 16 March 2020; Published: 18 March 2020

check for updates

\begin{abstract}
Joint pain and osteoarthritis (OA) are some of the most common causes of lameness in horses, and most of the available treatments focus on symptomatic relief without a disease-modifying effect. TRPV1 is a potential target for treating joint diseases, including OA, and the present study aims to investigate if the TRPV1 receptor is present in equine articular tissue and determine whether the number of receptors is upregulated in joint inflammation. Metacarpo/metatarsophalangeal (MCP/MTP) joints from 15 horses euthanised for reasons unrelated to this study were included. Based on synovial fluid analysis, macroscopic evaluation, and magnetic resonance imaging (MRI), joints were divided into two groups: healthy joints and joints with pathology. ELISA analysis was performed on synovial tissue harvested from all joints. TPRV1 was found in all joints. The mean concentration of TRPV1 compared to total protein in healthy joints $\left(8.4 \times 10^{-7} \mathrm{ng} / \mathrm{mL}\right)$ and joints with pathology $\left(12.9 \times 10^{-7} \mathrm{ng} / \mathrm{mL}\right)$ differed significantly ( $p=0.01, t$-test with Welch correction). Quantitative real-time reverse transcriptase PCR analysis was performed on RNA isolates from synovial tissue from all joints. TRPV1 mRNA expression ratio normalized to glyceraldehyde 3-phosphate dehydrogenase (GAPDH) in healthy joints (0.16 (SD: 0.19)) and joints with pathology (0.24 (SD: 0.14)) did not differ significantly ( $p=0.43, t$-test with Welch correction). mRNA expression of interleukin-6 (IL-6) and tumor necrosis factor alpha (TNF- $\alpha$ ) was very low for both groups. In conclusion, TRPV1 was detected both on mRNA and the protein level, with a higher expression of TRPV1 in samples from joints with pathology. Future studies will determine the clinical potential of equine TRPV1 as a target in the management of joint pain and inflammation.
\end{abstract}

Keywords: TRPV1; osteoarthritis; capsaicin; WORMS

\section{Introduction}

Joint pain and osteoarthritis (OA) are some of the most commonly reported causes of lameness and retirement in horses. One study showed that in a population of 797 horses and ponies from Great Britain, 13.9\% suffered from symptomatic OA [1]. Equine OA is a disease process in synovial joints characterised by the destruction of articular cartilage, subchondral bone sclerosis, and marginal osteophyte formation, often accompanied by joint effusion and synovitis [2,3]. The most commonly 
described aetiology is trauma-either as a single event or as a series of microtrauma. This will induce an inflammatory response, which, in turn, will drive the process of articular cartilage breakdown and remodelling of the surrounding bone [4]. Consequently, horses diagnosed with OA are often retired or euthanised.

There is a broad spectrum of treatments for equine OA. Most of them are anti-inflammatory and pain-relieving without a true disease-modifying effect, although regenerative medicine in regard to equine $\mathrm{OA}$ is a rapidly evolving area [5-8]. Two of the drug groups most commonly used for treating the symptoms related to equine OA are nonsteroidal anti-inflammatory drugs (NSAIDs) and intra-articular corticosteroids, often in combination. NSAIDs are predisposing for gastrointestinal ulceration and are potentially nephrotoxic, and corticosteroids are potentially chondrotoxic [9-12]. In human medicine, so-called disease-modifying osteoarthritis drugs (DMOADs) are being investigated in an attempt to stop the disease progression, as well as being pain-relieving and anti-inflammatory. However, an effective disease-modifying drug has not yet been developed [13].

Several authors point to the transient receptor potential vanilloid 1 (TRPV1) ion channel as a possible target for new ways of treating joint disease including OA [14-16]. TRPV1 is a nonselective cation channel which is expressed in various tissues. It is also known as the "chili receptor" and is primarily activated by capsaicin, which is the pungent substance in chili peppers. Besides capsaicin, it can be activated by several other chemicals as well as heat, $\mathrm{pH}$, and voltage [17-20]. Regarding joints and the sensory pathways related to these, TRPV1 has mainly been identified in C-type neurons, which account for a slower, deeper pain sensation than A-delta fibres [21]. TRPV1 receptors have been found in chondrocytes, macrophages, osteoclasts, osteoblasts and synovial fibroblasts [22-26], and it is generally established that activation of the receptor has a proinflammatory effect and that inhibition will lead to decreased pain and inflammation. $[15,16]$.

Upregulation of TRPV1 in the articular tissue in connection with inflammation has been shown in multiple species, including humans, mice and rats, and the receptor has been proven to play an important role not only in the development of oedema and hyperalgesia, but also in the destruction of cartilage and surrounding bone, as seen in OA joints [15,26-29]. These results highlight the potential of TRPV1 as a promising target for future DMOADs.

Surprisingly, not only deactivation of TRPV1, but also prolonged activation of the receptor will lead to analgesia due to the depletion of neuropeptides and subsequent desensitization of the C-fibres [30], hence both TRPV1-antagonists and agonists have shown promising results in pain management [14,16,26,31]. This has been further reviewed by Kelly [15] and Galindo et al. [16]. Due to the above-mentioned findings, TRPV1 antagonists have been investigated both for their analgesic and anti-inflammatory properties [31,32]. However, systemic administration of the majority of the tested TRPV1 antagonists have caused hyperthermia in dogs and humans [32,33]. Intra-articular treatment might require a lower dosage with a subsequent reduced risk of side-effects [31]. Therefore, intra-articular treatment should be investigated further.

TRPV1 has been suggested as a target for equine drugs, and mRNA coding for the receptor has been found in various equine nerves, but until now, the expression of TRPV1 in equine articular tissues has not been investigated $[34,35]$. Consequently, the aim of the present study was to identify the TRPV1 receptor in equine synovial tissue, and to investigate whether there was an upregulation in connection with joint pathology, as seen in other species.

\section{Materials and Methods}

This project was approved by the Ethical and Administrative Committee at Department of Veterinary Clinical Sciences, Faculty of Health and Medical Sciences, University of Copenhagen (2019-021). All horses were included after informed consent from the owner. 


\subsection{Animals and Sample Collection}

Fifteen client-owned horses euthanised at the Large Animal Teaching Hospital, University of Copenhagen, for reasons unrelated to this research project, were included. All horses had to be $>1$ year of age [36] and the following information was registered for each horse: age, gender, breed, use, reason for euthanasia, history of lameness, previous synovial fluid analysis if applicable, previous diagnostic imaging if applicable. The population consisted of six mares and nine geldings between three and 25 years of age; the breeds included Icelandic horses (5), Danish Warmblood (3), Standardbred (2), Jutland Draft Horses (2), Quarter Horses (1), Norwegian Fjord horses (1), and a mixed-breed pony (1).

In total, 11 metacarpophalangeal and four metatarsophalangeal (MCP/MTP) joints were collected. After euthanasia, the distal limbs were removed at the carpal or tarsal joint to obtain the MCP/MTP joints. The limbs were stored at $5{ }^{\circ} \mathrm{C}$ until magnetic resonance imaging (MRI) was performed (within 48 hours after euthanasia). Synovial fluid from the MCP/MTP joints was collected into an EDTA tube and stored at $5{ }^{\circ} \mathrm{C}$ until analysis (within $24 \mathrm{~h}$ ). After diagnostic imaging, the joint space was opened aseptically, macroscopic evaluation of the cartilage was performed, and digital photos were obtained to document joint status. The synovial membrane was harvested by dissection with rat tooth forceps and a scalpel, transferred into cryotubes, snap frozen in liquid nitrogen, and stored at $-80{ }^{\circ} \mathrm{C}$.

Joints were divided into three predefined groups (Table 1) based upon history, clinical examination, standard synovial fluid analysis, high-field MRI, and macroscopic evaluation of the joint surfaces-see detailed descriptions of methods below.

Table 1. Categorization of joint disease and division of horses into three groups (total nucleated cell count (TNCC); magnetic resonance imaging (MRI); whole organ MRI score (WORMS); Ymetacarpophalangeal (MCP); metatarsophalangeal (MTP)).

\begin{tabular}{lll}
\hline No Joint Pathology (Group A) & Osteoarthritis (Group B) & Arthritis (Group C) \\
\hline & - A history of continuous or & \\
non-continuous lameness $>3$ & \\
months of the limb in question & - Symptoms (acute lameness, \\
- Minimum 1 year of age [36] and & and/or & effusion) of $1-7$ days' duration and \\
- No known history of lameness of & - Positive MCP/MTP joint block or & - Synovial fluid compatible with \\
the limb in question and & nerve blocks affecting this joint & acute synovitis (TNCC $>1 \times 10^{9} / \mathrm{L}$ \\
- Normal synovial fluid analysis & during the diagnostic work-up & and/or protein $>25$ g/L) and/or \\
(clear yellow, viscous, protein $<20$ & and/or & $>85 \%$ neutrophils in cases with \\
g/L, TNCC $<1 \times 10^{9} / \mathrm{L},<10 \%$ & - Synovial fluid can have increased & septic arthritis [38,39] and \\
neutrophils) (adapted from [37]) & TNCC but it should mainly be & - No changes on MRI compatible \\
and & mononuclear cells, i.e., not & with Osteoarthritis, i.e., WORMS \\
- No changes on MRI compatible & compatible with acute arthritis (92) & $<10$ points and \\
with chronic arthrosis, i.e., & and/or & - Osteoarthritic changes graded $<4$ \\
WORMS $<10$ points and & Changes on MRI compatible with & points during macroscopic \\
- Osteoarthritic changes graded $<4$ & osteoarthritis, i.e., WORMS & evaluation of the joint \\
points during macroscopic & graded 10 points or above and/or & \\
evaluation of the joint & - Osteoarthritic changes graded & \\
& four points or above during & \\
& macroscopic evaluation of the joint & \\
\hline
\end{tabular}

\subsection{Magnetic Resonance Imaging}

MRI was performed in a 3T high-field scanner (Magnetom Verio: Siemens Healthineers, Erlangen Germany) using a dedicated 15-channel transmit/receive knee coil. The MCP/MTP joints were placed in the center of the coil. The protocol used is listed in Table 2.

All MR images were analysed by a board-certified specialist in veterinary diagnostic imaging (S.A., Diplomate of the American College of Veterinary Radiology) and scored using a whole organ MRI score (WORMS) modified from Smith et al. [40]. Eight regions were defined in the MCP/MTP joint: lateral and medial MC3/MT3 condyles (I-II), sagittal ridge (III), lateral and medial proximal phalangeal 
joint (P1) (IV-V), sagittal groove (VI), and lateral and medial sesamoids (VII-VIII) (Figure 1). Each region was scored using the criteria listed in Table 3 (0-19 points/region). Synovial thickening and joint effusion were given maximum of one point each for the entire joint. Final scores were summed to yield a WORMS for the entire MCP/MTP joint (0-154 points). A cut-off score was set at 10 points, i.e., WORMS $>10$ was regarded as OA.

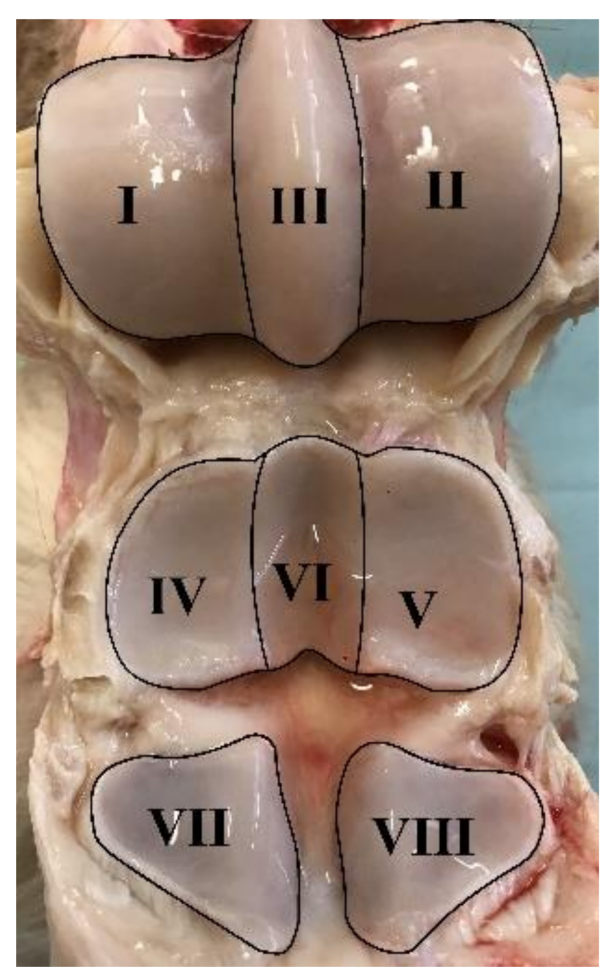

Figure 1. Regions defined in the metacarpophalangeal/ metatarsophalangeal joints. 
Table 2. Magnetic resonance sequences used. Repetition time (TR); echo time (TE); inversion time (TI); flip angle (FA); field of view (FOV); pixel (Px); number of excitations (NEX).

\begin{tabular}{|c|c|c|c|c|c|c|c|c|c|c|c|}
\hline & TR (ms) & TE (ms) & TI (ms) & $\begin{array}{c}\text { Slice } \\
\text { Thickness } \\
(\mathrm{mm})\end{array}$ & FA $\left(^{\circ}\right)$ & FOV (mm) & $\begin{array}{c}\text { Echo Train } \\
\text { length }\end{array}$ & $\begin{array}{l}\text { Bandwidth } \\
\text { (Hz/Px) }\end{array}$ & Matrix & NEX & $\begin{array}{l}\text { Scan Time } \\
\text { (min) }\end{array}$ \\
\hline $\begin{array}{c}\text { Axial_fse_blade } \\
\text { fatsat }\end{array}$ & 5000 & 26 & - & 2.5 & 145 & 160 & 9 & 318 & $384 \times 384$ & 2 & 06:02 \\
\hline Coronal_fse_T1W & 700 & 16 & - & 2.5 & 150 & 160 & 3 & 260 & $224 \times 320$ & 2 & 02:09 \\
\hline $\begin{array}{c}\text { Coronal_fse_T2W } \\
\text { fatsat }\end{array}$ & 5000 & 61 & - & 2.5 & 150 & 160 & 11 & 220 & $224 \times 320$ & 2 & $06: 42$ \\
\hline Coronal_STIR & 4900 & 32 & 220 & 2.5 & 150 & 160 & 10 & 252 & $224 \times 320$ & 2 & $02: 53$ \\
\hline Sagittal_fse_PDW & 5000 & 19 & - & 2.5 & 150 & 160 & 8 & 407 & $307 \times 384$ & 1 & $06: 32$ \\
\hline $\begin{array}{c}\text { T1W_Vibe_ISO } \\
\text { 3D }\end{array}$ & 11.6 & $05: 39$ & - & 0.6 & 10 & 160 & - & 190 & $256 \times 256$ & 1 & $03: 45$ \\
\hline Total Scan Time: & & & & & & & & & & & $33: 06$ \\
\hline
\end{tabular}


Table 3. Modified whole organ magnetic resonance score (WORMS) for the metacarpophalangeal/ metatarsophalangeal joints.

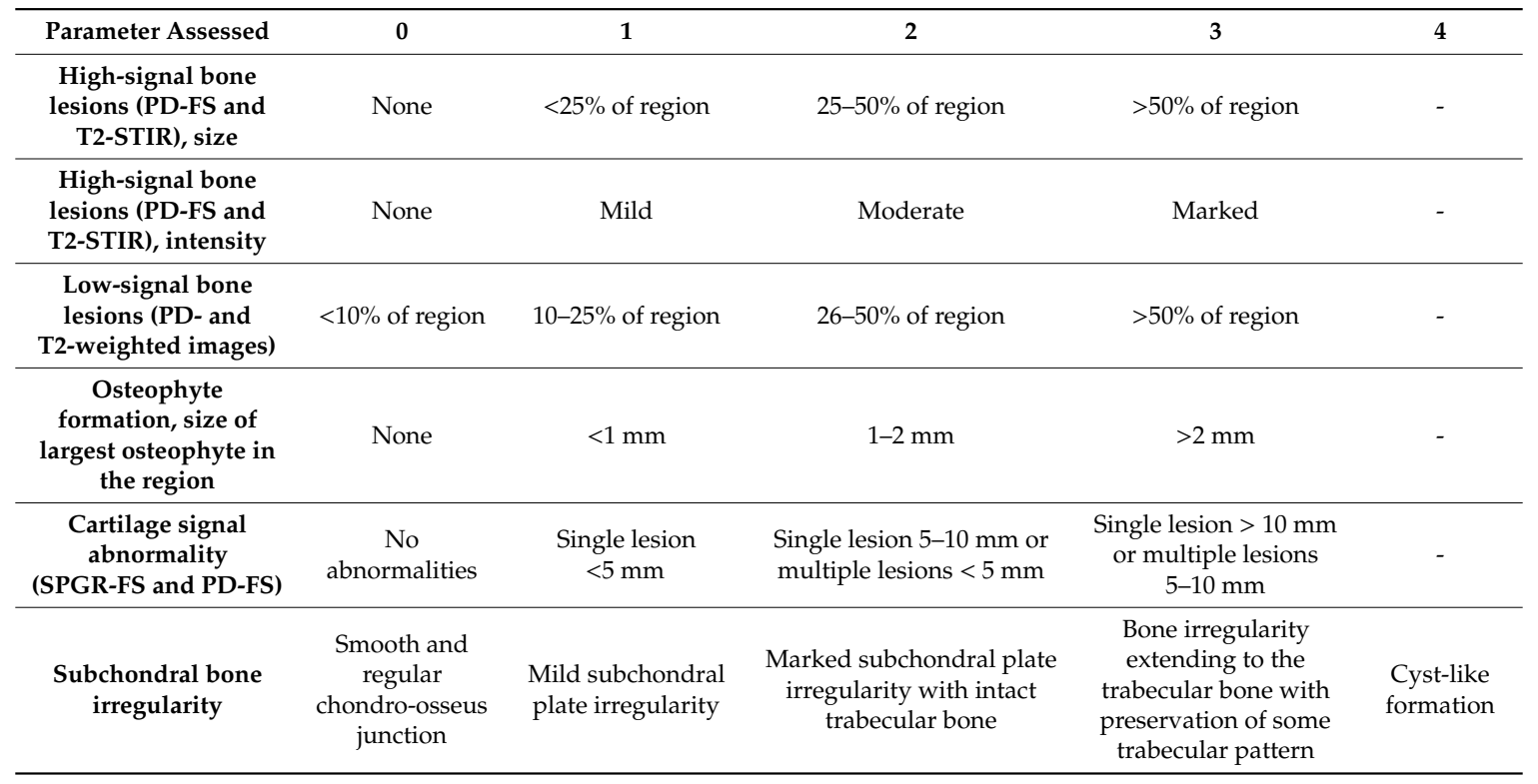

\subsection{Macroscopic Evaluation}

Macroscopic evaluation was performed using a scoring system adapted from McIlwraith et al. [41]. Each of the eight regions described above in the MCP/MTP joint was scored using the system listed in Table 4 . Each region was given between 0-6 points, and the scores were summed to yield an overall macroscopic evaluation score (0-48).

Table 4. Scoring system for macroscopic evaluation of equine joint surfaces [41].

\begin{tabular}{lclll}
\hline $\begin{array}{c}\text { Type of Pathology } \\
\text { Assessed }\end{array}$ & $\mathbf{0}$ & \multicolumn{1}{c}{$\mathbf{1}$} & \multicolumn{1}{c}{$\mathbf{2}$} \\
\hline Wear lines & None & $\begin{array}{l}\text { 1 or 2 partial-thickness } \\
\text { wear lines }\end{array}$ & $\begin{array}{l}\text { 3-5 partial thickness or } \\
1-2 \text { full-thickness } \\
\text { wearlines }\end{array}$ & $\begin{array}{l}>5 \text { partial thickness } \\
\text { or }>2 \text { full-thickness } \\
\text { wear lines }\end{array}$ \\
\hline Erosions & None & $\begin{array}{l}\text { Partial-thickness erosion, } \\
<5 \mathrm{~mm} \text { in diameter }\end{array}$ & $\begin{array}{l}\text { Partial thickness erosion, } \\
>5 \mathrm{~mm} \text { in diameter }\end{array}$ & $\begin{array}{l}\text { Full thickness } \\
\text { erosion }\end{array}$ \\
\hline
\end{tabular}

\subsection{Synovial Fluid Analysis}

Protein concentration $(\mathrm{g} / \mathrm{L})$ was measured with a refractometer (ATAGO Co. Ltd., Tokyo, Japan). Total Nucleated Cell Count (TNCC) was performed manually using a Bürker-Türk chamber ("Brigthline", Marienfeld VWR, Søborg, Denmark). A line smear was stained using Hematoxylin and Eosin stain (HE) for future reference. A small portion of the synovial fluid was used for cytospin and subsequent smear, HE staining, and differential count. The rest of the synovial fluid was centrifuged for $10 \mathrm{~min}$ at $2500 \mathrm{~g}$, and the supernatant was harvested and stored at $-20^{\circ} \mathrm{C}$.

\subsection{ELISA}

Synovial tissue from all joints in the study was analysed using a commercially available ELISA assay (horse transient receptor potential cation channel subfamily V, member 1 (TRPV1) ELISA Kit, Cat.No.: MBS090478 from MyBioSource, San Diego, CA, USA) read with a Multiskan EX ELISA-reader (Thermo Fischer Scientific, Waltham, MA, USA). The synovial tissue was prepared according to the ELISA kit manual: $20 \mathrm{mg}$ tissue was added to $200 \mu \mathrm{L}$ PBS (Cat.No.: A9177.0100, Applichem GmbH, Darmstadt, Germany) and homogenised using an IKA T10 Basic Ultra-Turrax tissue homogeniser (IKA ${ }^{\circledR}$-Werke 
$\mathrm{GmbH} \&$ Co., Staufen, Germany) while kept below $10^{\circ} \mathrm{C}$. The homogenate was centrifuged for approximately $20 \mathrm{~min}$ at $1020 \times g$ at $4{ }^{\circ} \mathrm{C}$ and the supernatant was collected. Total protein concentration was determined by optical density measurement (NanoDrop TM Spectrophotometer (Thermo Fischer Scientific, Waltham, MA, USA)), and the samples were stored at $-20^{\circ} \mathrm{C}$ until analysis. Since TRPV1 is a cell membrane-associated receptor and in order to standardize for total amount of cells between samples, TRPV1 concentrations were normalized to total protein concentration for each sample, yielding results organised as the TRPV1 concentration as a ratio of the total protein concentration.

\subsection{RNA Isolation and Quantitative Real-Time Reverse Transcriptase PCR Analysis}

Synovial membrane tissue $(60 \mathrm{mg}$ ) was lysed in $1 \mathrm{~mL}$ TRI Reagent (Molecular Research Centre, Inc. Cincinnati, OH, USA) and homogenised using an IKA T10 Basic Ultra-Turrax tissue homogeniser while kept below $10^{\circ} \mathrm{C}$. The homogenate was phase separated by adding $0.2 \mathrm{~mL}$ chloroform (Cat. No.: 24.751.000, Th. Geyer, Roskilde, Denmark), shaken vigorously for 15 seconds, allowed to stand for $15 \mathrm{~min}$ at room temperature (RT), and centrifuged at $12,000 \times \mathrm{g}$ for $15 \mathrm{~min}$ at $4{ }^{\circ} \mathrm{C}$. The upper phase containing the RNA was transferred to a fresh tube. RNA was precipitated by adding $0.5 \mathrm{~mL}$ 2-propanol (Cat.No.: 11.361.000, Th. Geyer, Roskilde, Denmark), incubated for $8 \mathrm{~min}$ at RT, followed by centrifugation at $12,000 \times g$ for $8 \mathrm{~min}$ at $4{ }^{\circ} \mathrm{C}$. After removing the supernatant, the RNA pellet was washed by adding $1 \mathrm{~mL}$ 75\% ethanol (Cat.No.: 698191, Glostrup Pharmacy, Glostrup, Denmark) and centrifugation at $7500 \times \mathrm{g}$ for $5 \mathrm{~min}$ at $4{ }^{\circ} \mathrm{C}$. The supernatant was removed, and the pellet was air dried for 5-7 min. The pellet was resuspended in $70 \mu \mathrm{L}$ double-distilled water and incubated for $10 \mathrm{~min}$ at $60{ }^{\circ} \mathrm{C}$. Total RNA concentration was determined by optical density measurement (NanoDrop TM Spectrophotometer), and total RNA isolates were kept at $-80^{\circ} \mathrm{C}$ until further processing.

cDNA was synthesized from $1.0 \mu \mathrm{g}$ total RNA. Reverse transcriptase PCR mastermix (Promega, Madison, WI, USA) consisted of $5 \mu \mathrm{L}$ RT buffer, $1.3 \mu \mathrm{L}$ dNTP mix $(10 \mu \mathrm{M})$ (Thermo Fischer Scientific, Waltham, MA, USA), $0.25 \mu \mathrm{L}$ random hexamer primers $(2 \mu \mathrm{g} / \mu \mathrm{L})$ (TAG Copenhagen, Copenhagen, Denmark), $0.25 \mu \mathrm{L}$ Oligo-dT primers $(0.5 \mu \mathrm{g} / \mu \mathrm{L})$ (TAG Copenhagen, Copenhagen, Denmark), $0.8 \mu \mathrm{L}$ RNasin ${ }^{\circledR}$ Plus RNase inhibitor (40 U/ $\mu \mathrm{L}$ ) (Promega, Madison, WI, USA), $1 \mu \mathrm{L}$ M-MLV Reverse Transcriptase (200 U/ $\mu \mathrm{L}$ ) (Promega, Madison, WI, USA), and sterile water. Reverse transcription was performed in a BIOmetra ${ }^{\circledR}$ T-Gradient thermocycler (Thermo Fischer Scientific, Waltham, MA, USA) at $25^{\circ} \mathrm{C}$ for $10 \mathrm{~min}, 42^{\circ} \mathrm{C}$ for $60 \mathrm{~min}$, and $95^{\circ} \mathrm{C}$ for $5 \mathrm{~min}$. Samples were stored at $-20^{\circ} \mathrm{C}$.

Species-specific intron-spanning equine primers were used to amplify TRPV1, interleukin- 6 (IL-6), tumor necrosis factor alpha (TNF- $\alpha$ ) and glyceraldehyde 3-phosphate dehydrogenase (GAPDH) (reference gene). Primers are listed in Table 5. Quantitative real-time reverse transcriptase PCR (qPCR) was performed in triplicates using LightCycler ${ }^{\circledR}$ Fast Start DNA Master SYBR Green I and LightCycler ${ }^{\circledR}$ Real-Time PCR System (Roche, Basel, Switzerland). Results are presented as relative quantitative expression ratios between the target genes (TRPV1, IL-6, TNF- $\alpha$ ) and reference gene (GAPDH).

Table 5. Species-specific primers.

\begin{tabular}{|c|c|c|c|}
\hline Primer Name & Forward Primer $5^{\prime}-3^{\prime}$ & Reverse Primer 5'-3' & Reference/Accession Number \\
\hline TRPV1 & $\begin{array}{l}\text { TTG AGG ACG GGA } \\
\text { AGA ATG AC }\end{array}$ & $\begin{array}{l}\text { GAT GAG CAT GTT } \\
\text { GAT CAG GA }\end{array}$ & Berg, LC/XM_014727972.2 \\
\hline IL-6 & $\begin{array}{l}\text { ATG GCA GAA AAA } \\
\text { GAC GGA TG }\end{array}$ & $\begin{array}{l}\text { GGG TCA GGG GTG } \\
\text { GTT ACT TC }\end{array}$ & Haneda et al. [42] \\
\hline $\mathrm{TNF} \alpha$ & $\begin{array}{l}\text { GAG GGA AGA GCA } \\
\text { GTT ACC GAA TG }\end{array}$ & $\begin{array}{l}\text { GGC TAC AGG CTT } \\
\text { GTC ACT TGG }\end{array}$ & Berg, LC/NM_001081819.2 \\
\hline GAPDH & $\begin{array}{l}\text { GGG TGG AGC CAA } \\
\text { AAG GGT CAT CAT }\end{array}$ & $\begin{array}{l}\text { AGC TTT CTC CAG } \\
\text { GCG GCA GGT CAG }\end{array}$ & Iqbal et al. [43] \\
\hline
\end{tabular}

\subsection{Statistics}

Data sets were tested for normality using a Shapiro-Wilks test, and subsequently an unpaired t-test with assumed Gaussian distribution was used to analyse for differences between groups. Welch 
correction was applied. All data analysis was performed using GraphPad Prism version 8.00 for Windows [44]. The significance level was set at $p<0.05$.

\section{Results}

\subsection{Division into Groups}

Using the criteria listed in Table 1, the horses were divided into following groups:

A detailed list of results for each horse can be seen in Appendix A. Due to only one horse being in group $C$, groups $B$ and $C$ were pooled (all joints with pathology) and compared to group $A$ (all healthy joints) for all analyses (Table 6). Age differed significantly between Group A (mean age 8.3 years) and Group B (mean age 15.3 years) $(p=0.03$ ), and between group A and groups B and C (mean age 15.4 years) $(p=0.02)$. Representative images of MRI and macroscopic findings are shown in Figures 2 and 3.

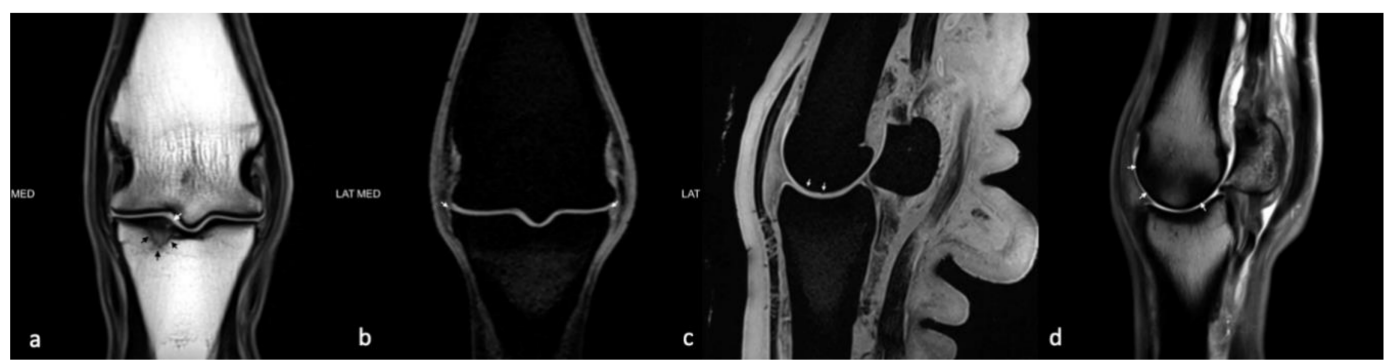

Figure 2. Image panel representative of some of the MRI findings from the study. (a) Dorsal plane T1W TSE image at the mid aspect of the metacarpophalangeal joint of horse \#7 showing a fissure within the subchondral bone plate of the proximal phalanx along the medial aspect of the sagittal groove (white arrows) that is surrounded by sclerosis and intra-osseous fluid accumulation (black arrows). (b) Dorsal plane T1W VIBE image of horse \#9 near the dorsal aspect of the metacarpophalangeal joint showing osteophytes arising from the dorsal, proximal, abaxial margins of the proximal phalanx (white arrows). (c) Sagittal plane T1W VIBE image at the mid aspect of the medial third metacarpal condyle showing irregularity of the subchondral bone plate of the third metacarpus and signal alteration of the overlying articular cartilage (white arrows). (d) Sagittal plane PDW TSE image of the medial aspect of the third metacarpal condyle showing regions of low signal bone intensity of the dorsal and palmar aspects of the condyle as indicated by the white arrows.

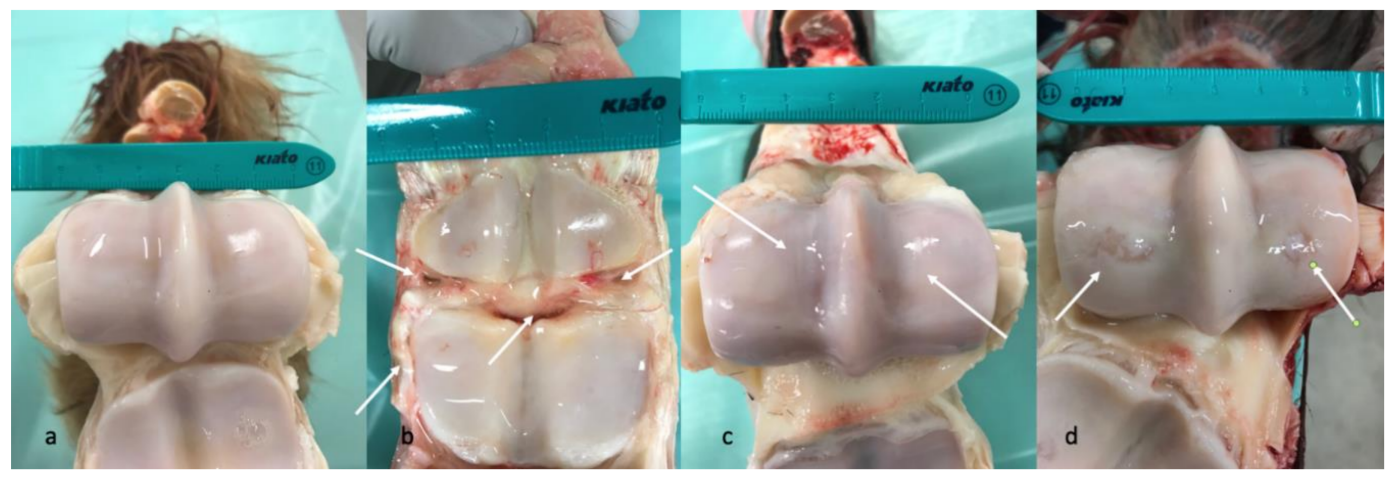

Figure 3. Image panel representative of some of the findings from the macroscopic pathology evaluations described in the study. (a) The opened fetlock of horse \#6 showing smooth glistening cartilage surfaces with no synovial hyperplasia and no signs of wear lines or erosions. (b) The opened fetlock of horse \#3 showing a moderate to marked degree of synovial hyperplasia (white arrows). (c) The opened fetlock of horse \#14 showing a mild to moderate degree of superficial wear lines on both condyles of the third metacarpal bone (white arrows). (d) The opened fetlock of horse \#4 showing severe full thickness erosions of the cartilage of the central distal parts of the medial and lateral condyles of the third metacarpal bone (white arrows). 
Table 6. Number of horses in groups A, B, and C.

\begin{tabular}{llll}
\hline & No Joint Pathology (A) & Chronic Arthrosis (B) & Acute Arthritis (C) \\
\hline Number of Horses & 6 & 8 & 1 \\
\hline
\end{tabular}

\subsection{Levels of TRPV1 in Metacarpo-Phalangeal/Metatarso-Phalangeal (MCP/MTP) Joints}

TRPV1 receptor was detected in all equine synovial tissue samples. TRPV1 concentration as a ratio of total protein in joints with pathology (mean: $12.9 \times 10^{-7}$ (SD: 2.9)) differed significantly from healthy joints (mean: $\left.8.66 \times 10^{-7}(\mathrm{SD}: 3.02)\right)(p=0.01)$ (Figure 4$)$. Comparing group A and B horses without including the one group $\mathrm{C}$ horse does not change the results $(p=0.03)$.

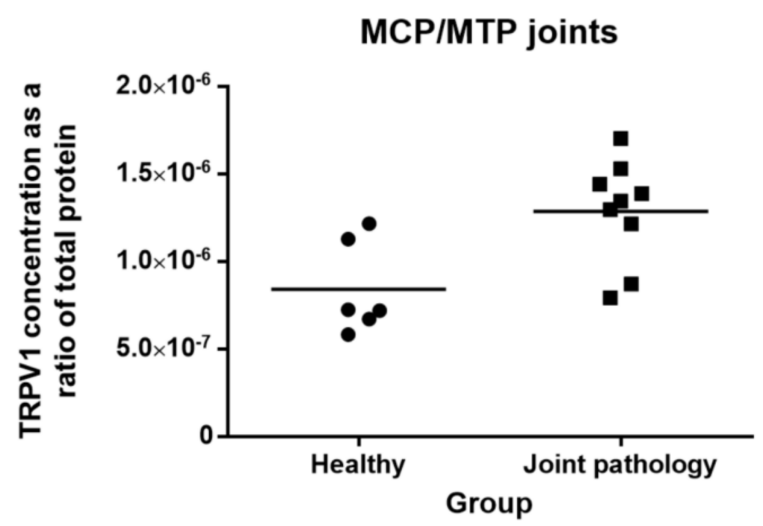

Figure 4. Concentration of transient receptor potential vanilloid 1(TRPV1) protein in synovial membrane tissue from MCP/MTP joints $(\mathrm{ng} / \mathrm{mL})$ relative to total protein $(\mathrm{ng} / \mathrm{mL})$. Symbols indicate individual joints (circles = healthy; squares $=$ joint pathology). The mean is indicated by the horizontal bar.

\subsection{Levels of mRNA Coding for TRPV1, IL-6 and TNF- $\alpha$ in MCP/MTP Joints}

TRPV1 mRNA was detected in all equine synovial tissue samples. TRPV1 expression ratios normalized to GAPDH in joints with pathology (mean: 0.24 (SD: 0.14)) did not differ significantly from healthy joints (mean: 0.16 (SD: 0.19)) $(p=0.43)$ (Figure 5). Comparing group A and B horses without including the one group $C$ horse does not change this result $(p=0.45)$. mRNA expression of IL-6 and TNF- $\alpha$ was very low for both groups.

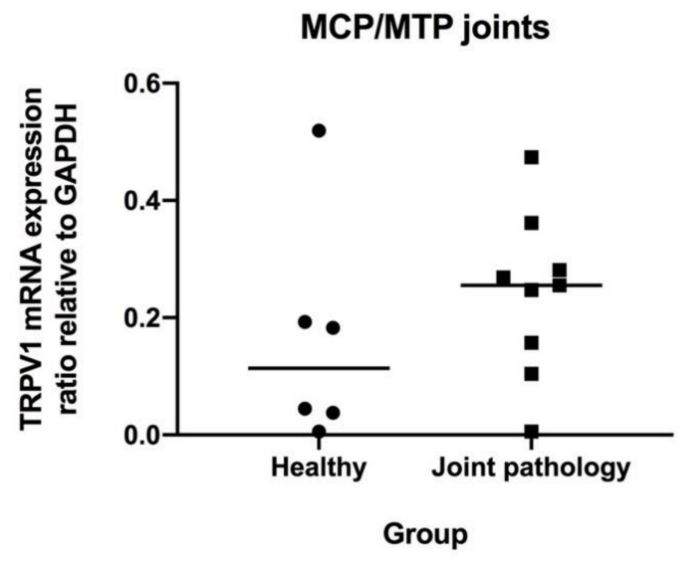

Figure 5. TRPV1 mRNA expression ratio relative to glyceraldehyde 3-phosphate dehydrogenase (GAPDH) in synovial membrane tissue from metacarpo-phalangeal/metatarso-phalangeal (MCP/MTP) joints. Symbols indicate individual joints (circles = healthy; squares = joint pathology). Mean is indicated by horizontal bar. 


\section{Discussion}

The present study demonstrated that TRPV1 was present as mRNA and protein in the equine synovial membrane in healthy and diseased joints. These results are consistent with previous studies, where TRPV1 has been found in synovial tissue from several other species [26-28], and in both neural and respiratory tissue in the horse [45].

Regulation of TRPV1 in diarthrodial joints has been studied in rats and humans. In a mono-iodo-acetate-induced (MIA) arthritis model in rats, 71\% of sensory neurons stained positive for TRPV1 when using immunohistochemistry, compared to $54.3 \%$ of sensory neurons in control rats injected with saline [27]. Another study compared TRPV1 immunoreactivity in synovial sections from human patients with OA, rheumatoid arthritis (RA), and post mortem (PM) controls without known joint pathology, and showed an increased fraction of TRPV1 immunoreactivity in synovial sections from patients with OA (7.3\%) and RA (5.2\%) compared to PM controls (0.0\%) [26]. The present study revealed a significant upregulation of TRPV1 protein concentration in horses with joint pathology compared to healthy controls. However, as a similar difference could not be shown for TRPV1 mRNA, the conclusion regarding upregulation during disease is not unequivocal, although visual inspection of Figure 5 seems to indicate a tendency towards a higher level in the group with joint pathology.

One factor that may have affected the results in the present study is the very heterogenous nature of the diseased group. Horses were euthanised for other reasons than this research project, and were therefore not selected for symptomatic and/or longstanding joint problems. Consequently, only very few included horses had a clinical history of diagnosed joint pathology, and assignment into the pathology group was based solely on macroscopic and MRI findings. This differs from other studies regarding TRPV-1 expression [27]. None of the joints in the present study scored maximum points in the WORMS or during the macroscopic evaluation and are therefore considered less affected by intra-articular inflammation than the MIA-induced joints in the study by Fernihough et al. [27]. The methods and criteria used for categorization of joint disease status are criteria used both in the literature and in the clinic. We therefore believe this to be a clinically relevant group of horses, representing the stage just before the need for intervention. However, further studies including horses with clinical disease and lameness might elucidate whether TRPV1 is truly upregulated during disease.

The synovial membrane is a highly reactive tissue that changes not only in cellular activity, but also in morphology when reacting to inflammation. The reactive synovial lining will increase from only two to three cell layers in the healthy joint to multiple layers in the inflamed joint. This is a challenge for any study working with harvested synovial tissue especially from healthy joints due to the difficulty in separating the synovial layer from the sub-synovial tissue, as acknowledged by other studies [40]. In this study, the synovial tissue was harvested carefully using rat tooth forceps and a scalpel, relying on the gross appearance of the synovial tissue, which has a "fatty", shiny presentation. Another method described is to use tissue shavers to collect synovial tissue, but this has mostly been done in joints with synovial hyperplasia and, hence, more cell layers [46]. Since the cell density in the synovial lining is very dense, with an almost epithelial appearance compared to the more fibrous and far less cell dense sub-synovial tissue, the risk of this affecting the overall results is considered low.

In the present study, MRI was used to assess joint pathology before dividing joints into groups. MRI has been found to be superior to radiography, when assessing non-cartilaginous changes in equine MCP joints with OA using macroscopic and histological evaluations as the gold standard [47,48]. Furthermore, MRI has been found to be considerably more sensitive than radiography when evaluating osteophytes, fissure fractures, subchondral bone damage, trabecular bone damage, or when discriminating joint effusion from soft tissue thickening [49,50]. Other studies have investigated the use of MRI in horses with lameness located to the MCP/MTP region without radiographic evidence of pathology. Most of these horses were successfully diagnosed using MRI, including horses with OA, chronic subchondral bone injury, fracture pathology or osteochondral defects, yet without a sufficient change in bone density to be observed on radiographs [51-54]. 
Most studies using MRI in horses have been performed in low- or high-field scanners ranging from 0.25-1.5 Tesla. The scanner used in the present study was a 3 Tesla high-field scanner with protocols adjusted to this magnetic flux density, making it capable of producing more detailed images (Figure 2). The OA changes on the MR images were scored using a modified whole organ MRI score (WORMS) based on an article by Smith et al. [40], who developed a similar score for the equine carpal joint. The WORMS used in the present study only included characteristics deemed statistically significant by Smith et al. [40], but the use of WORMS in equine imaging is still new, and the method is not yet validated. To the authors' knowledge, no studies have determined a WORMS cut-off value for equine OA. In human medicine, WORMS is used as a research tool to grade osteoarthritic changes, but a cut-off value has yet to be defined [55]. Since it was not possible to extrapolate a cut-off value to equine MCP/MTP joints, the final cut-off value was determined based on a comparison with the macroscopic evaluation. All joints were macroscopically assessed when opened. Synovial hyperplasia, fibrillation, wear lines, and cartilage defects were noted, and photographic images recorded following a standardized protocol were obtained and saved for reference (Figure 3). In general, there was good conformity between the MRI evaluation and the macroscopic evaluation (Appendix A).

The therapeutic role of TRPV1 is a quickly emerging subject in both human and veterinary medicine, and some authors have even referred to it as "the holy grail of pain management" [56]. Time and future studies will tell whether TRPV1 agonists or antagonists, alone or in combination with other drugs, will be an efficient way to treat pain and inflammation in joints as well as stopping the deleterious effects of equine OA. For future studies, we recommend a larger population of horses representing two groups: horses with no musculoskeletal problems and no OA changes, and horses which have been diagnosed with clinically manifested, symptomatic OA before euthanasia. This would ensure a more well-defined group of horses with symptomatic joint pathology. We also recommend further investigation of the presence and regulation of TRPV1 in the articular tissues, including the cartilage. Furthermore, if the future goal is to use the TRPV1 as a target for DMOADs, the next step will be to test the clinical response to either agonists or antagonists in horses. One study in dogs has shown very promising results in regard to efficient pain management with few or no side effects, when treating naturally occurring OA with a single intraarticular injection of resiniferatoxin, a TRPV1 agonist [31]. This protocol could easily be adapted for equine use and clinical trials could be undertaken.

In conclusion, the results from the present study show that TRPV1 is present in equine synovial membrane. It was not possible to unequivocally determine whether TRPV1 expression is upregulated in joints with pathology. Our results create a sound foundation for further investigations into TRPV1 as a local target for treatment of OA in horses.

Author Contributions: Conceptualization, C.L. and L.C.B.; methodology, all authors.; formal laboratory analysis, L.C.B., S.A., N.L.F. and A.F.G.v.B.; MRI protocol development, M.P.B., F.C.M. and S.A.; writing一original draft preparation, A.F.G.v.B., N.L.F., C.L. and L.C.B.; writing-review and editing, All authors.; visualization, A.F.G.v.B., N.L.F., C.L., L.C.B. and S.A.; project administration, C.L.; funding acquisition, C.L. All authors have read and agree to the published version of the manuscript.

Funding: This research was funded by "Foreningen KUSTOS" (a national non-profit foundation for equine research) and the University of Copenhagen.

Acknowledgments: We thank radiographers Frederik Hvid Mortensen and Janus Damm Nybring, Bispebjerg and Frederiksberg Hospitals, Copenhagen, Capital Area, Denmark, for performing all MRI scans. We thank laboratory technician Tina Roust, Department of Veterinary Clinical Sciences, University of Copenhagen for advice and help on all ELISA tests. We thank all horse owners who donated their horses to research and all staff of the Large Animal Teaching Hospital, University of Copenhagen, who helped recruit horses for the study.

Conflicts of Interest: The authors declare no conflict of interest. 


\section{Appendix A}

Table A1. Combined results from synovial fluid analysis, WORMS score and macroscopic evaluation of the metacarpo/metatarsophalangeal joints.

\begin{tabular}{|c|c|c|c|c|c|c|c|c|}
\hline \multirow[b]{2}{*}{ Horse no. } & \multicolumn{2}{|c|}{ Joint Evaluation } & \multicolumn{3}{|c|}{ Synovial Fluid Evaluation } & \multirow{2}{*}{\begin{tabular}{l}
\multicolumn{1}{c}{ ELISA } \\
TRPV1 Concentration \\
(ng/mL) Relative to Total \\
Protein $(\mathrm{ng} / \mathrm{mL})$
\end{tabular}} & qPCR & \multirow[b]{2}{*}{ Group } \\
\hline & $\begin{array}{l}\text { Macroscopic } \\
\text { Evaluation } \\
(0-56)\end{array}$ & $\begin{array}{l}\text { WORMS Total }(0-154) \\
\text { and Max Regional } \\
\text { Score }(0-19)\end{array}$ & $\begin{array}{l}\text { Protein } \\
(\mathrm{g} / \mathrm{L})\end{array}$ & TNCC $\left(\times 10^{9} / \mathrm{L}\right)$ & $\begin{array}{l}\text { Differential Count } \\
\text { (\% Neutrophils of } \\
\text { TNCC) }\end{array}$ & & $\begin{array}{l}\text { TRPV1 mRNA Expression } \\
\text { Relative to GAPDH }\end{array}$ & \\
\hline 1 & 0 & $6 / 2 *$ & 11 & 0.8 & 1.5 & $5.82 \times 10^{-7}$ & 0.183 & $\mathrm{~A}$ \\
\hline 2 & 1 & $8 / 2 *$ & 10 & 0.3 & 2.3 & $7.25 \times 10^{-7}$ & 0.038 & A \\
\hline 3 & 4 & $3 / 1^{*}$ & 4 & 1.6 & 1.2 & $7.92 \times 10^{-7}$ & 0.269 & B \\
\hline 4 & 8 & $17 / 5$ & 5 & 0.3 & 1.0 & $13.5 \times 10^{-7}$ & 0.474 & B \\
\hline 5 & 3 & $3 / 2$ & 14 & 3.8 & 2.0 & $14.4 \times 10^{-7}$ & 0.247 & $\mathrm{C}$ \\
\hline 6 & 0 & $6 / 1$ & 9 & 0.9 & 0.0 & $7.20 \times 10^{-7}$ & 0.045 & $\mathrm{~A}$ \\
\hline 7 & 1 & $20 / 10$ & 17 & 0.3 & 1.0 & $13.9 \times 10^{-7}$ & 0.157 & B \\
\hline 8 & 6 & $11 / 4$ & 2 & 0.7 & 2.0 & $15.3 \times 10^{-7}$ & 0.281 & B \\
\hline 9 & 2 & $11 / 3$ & 14 & 0.9 & 0.0 & $8.71 \times 10^{-7}$ & 0.104 & B \\
\hline 10 & 4 & $6 / 2$ & 22 & 4.7 & 0.5 & $17.0 \times 10^{-7}$ & 0.362 & B \\
\hline 11 & 5 & $11 / 4$ & 17 & 1.3 & 1.0 & $12.1 \times 10^{-7}$ & 0.006 & B \\
\hline 12 & 1 & $6 / 1$ & 1 & 0.4 & 0.0 & $6.71 \times 10^{-7}$ & 0.006 & A \\
\hline 13 & 2 & $6 / 2$ & 9 & 0.4 & $5.0^{* *}$ & $12.2 \times 10^{-7}$ & 0.193 & A \\
\hline 14 & 8 & $8 / 2$ & 5 & 4.1 & 3.0 & $13.0 \times 10^{-7}$ & 0.255 & B \\
\hline 15 & 0 & $3 / 1$ & 8 & 0.7 & 2.0 & $12.8 \times 10^{-7}$ & 0.520 & $\mathrm{~A}$ \\
\hline
\end{tabular}

${ }^{*}$ Gas was present in these joints, hence the evaluation of cartilage signal abnormality on MRI was impaired. Cartilaginous changes seen during the macroscopic evaluation were given emphasis when determining which groups these horses were assigned to. ${ }^{* *}$ Very few cells were present in this sample, hence the validity of this differential count is uncertain. 


\section{References}

1. Ireland, J.L.; Wylie, C.E.; Collins, S.N.; Verheyen KL, P.; Newton, J.R. Preventive health care and owner-reported disease prevalence of horses and ponies in Great Britain. Res. Vet. Sci. 2013, 95, 418-424. [CrossRef]

2. Nilsson, G. Lameness and pathologic changes in the distal joints and the phalanges of the standardbred horse. A correlative study. Acta Vet. Scnad. Suppl. 1973, 44, 83-96.

3. Mcllwraith, C.W. Current concepts in equine degenerative joint disease. J. Am. Vet. Med. Assoc. 1982, 180, 239-250. [PubMed]

4. McIlwraith, C.W.; Van Sickle, D.C. Experimentally induced arthritis of the equine carpus: Histological and histochemical changes in the articular cartilage. Am. J. Vet. Res. 1981, 42, 209-217. [PubMed]

5. Smith, S.B.; Clegg, P. Treatment of equine joint diseases Part 1: Pharmacological management of equine osteoarthritis (OA). Companion Anim. 2007, 12, 9-15. [CrossRef]

6. McIlwraith, C.W.; Frisbie, D.D.; Kawcak, C.E. Evaluation of intramuscularly administered sodium pentosan polysulfate for treatment of experimentally induced osteoarthritis in horses. Am. J. Vet. Res. 2012, 73, 628-633. [CrossRef]

7. Watson Levings, R.S.; Smith, A.D.; Broome, T.A.; Rice, B.L.; Gibbs, E.P.; Myara, D.A.; Viktoria Hyddmark, E.; Nasri, E.; Zarezadeh, A.; Levings, P.P.; et al. Self-Complementary Adeno-Associated Virus-Mediated Interleukin-1 Receptor Antagonist Gene Delivery for the Treatment of Osteoarthritis: Test of Efficacy in an Equine Model. Hum. Gen. Ther. Clin. Dev. 2018, 29, 101-112. [CrossRef]

8. Broeckx, S.Y.; Martens, A.M.; Bertone, A.L.; Van Brantegem, L.; Duchateau, L.; Van Hecke, L.; Dumoulin, M.; Oosterlinck, M.; Chiers, K.; Hussein, H.; et al. The use of equine chondrogenic-induced mesenchymal stem cells as a treatment for osteoarthritis: A randomised, double-blinded, placebo-controlled proof-of-concept study. Equine Vet. J. 2019, 51, 787-794. [CrossRef]

9. Moses, V.S.; Bertone, A.L. Nonsteroidal anti-inflammatory drugs. Vet. Clin. N. Am. Equine Pract. 2002, 18, 21-37. [CrossRef]

10. Karcher, L.F.; Dill, S.G.; Anderson, W.I.; King, J.M. Right dorsal colitis. J. Vet. Int. Med. 1990, 4, $247-253$. [CrossRef]

11. Byron, C.R.; Benson, B.M.; Stewart, A.A.; Pondenis, H.C. Effects of methylprednisolone acetate and glucosamine on proteoglycan production by equine chondrocytes in vitro. Am. J. Vet. Res. 2008, 69, 1123-1128. [CrossRef] [PubMed]

12. Fubini, S.L.; Todhunter, R.J.; Burton-Wurster, N.; Vernier-Singer, M.; Macleod, J.N. Corticosteroids alter the differentiated phenotype of articular chondrocytes. J. Orthop. Res. 2001, 19, 688-695. [CrossRef]

13. Karsdal, M.A.; Michaelis, M.; Ladel, C.; Siebuhr, A.S.; Bihlet, A.R.; Andersen, J.R.; Guehring, H.; Christiansen, C.; Bay-Jensen, A.C.; Kraus, V.B. Disease-modifying treatments for osteoarthritis (DMOADs) of the knee and hip: Lessons learned from failures and opportunities for the future. Osteoarthr. Cartil. 2016, 24, 2013-2021. [CrossRef] [PubMed]

14. Wong, G.Y.; Gavva, N.R. Therapeutic potential of vanilloid receptor TRPV1 agonists and antagonists as analgesics: Recent advances and setbacks. Brain Res. Rev. 2009, 60, 267-277. [CrossRef]

15. Kelly, S. TRPV1 antagonists in the treatment of osteoarthritis pain. Int. J. Clin. Rheum. 2015, 10, 161-175. [CrossRef]

16. Galindo, T.; Reyna, J.; Weyer, A. Evidence for Transient Receptor Potential (TRP) Channel Contribution to Arthritis Pain and Pathogenesis. Pharmaceuticals 2018, 11, 105. [CrossRef]

17. Oh, U.; Hwang, S.W.; Kim, D. Capsaicin activates a nonselective cation channel in cultured neonatal rat dorsal root ganglion neurons. J. Neurosci. 1996, 16, 1659-1667. [CrossRef]

18. Caterina, M.J.; Schumacher, M.A.; Tominaga, M.; Rosen, T.A.; Levine, J.D.; Julius, D. The capsaicin receptor: A heat-activated ion channel in the pain pathway. Nature 1997, 389, 816-824. [CrossRef]

19. Aneiros, E.; Cao, L.; Papakosta, M.; Stevens, E.B.; Phillips, S.; Grimm, C. The biophysical and molecular basis of TRPV1 proton gating. EMBO J. 2011, 30, 994-1002. [CrossRef]

20. Baez-Nieto, D.; Alvarez, O.; Brauchi, S.; Gonzalez, C.; Latorre, R. Voltage-Dependence in Thermo-Voltage Sensitive Channel TRPV1. A Delocalized Voltage Sensor? Biophys. J. 2013, 104, 456. [CrossRef]

21. Ioi, H.; Kido, M.A.; Zhang, J.Q.; Yamaza, T.; Nakata, S.; Nakasima, A.; Tanaka, T. Capsaicin receptor expression in the rat temporomandibular joint. Cell Tissue Res. 2006, 325, 47-54. [CrossRef] [PubMed] 
22. Engler, A.; Aeschlimann, A.; Simmen, B.R.; Michel, B.A.; Gay, R.E.; Gay, S.; Sprott, H. Expression of transient receptor potential vanilloid 1 (TRPV1) in synovial fibroblasts from patients with osteoarthritis and rheumatoid arthritis. Biochem. Biophys. Res. Commun. 2007, 359, 884-888. [CrossRef] [PubMed]

23. Gavenis, K.; Schumacher, C.; Schneider, U.; Eisfeld, J.; Mollenhauer, J.; Schmidt-Rohlfing, B. Expression of ion channels of the TRP family in articular chondrocytes from osteoarthritic patients: Changes between native and in vitro propagated chondrocytes. Mol. Cell. Biochem. 2008, 321, 135-143. [CrossRef] [PubMed]

24. Rossi, F.; Siniscalco, D.; Luongo, L.; De Petrocellis, L.; Bellini, G.; Petrosino, S.; Torella, M.; Santoro, C.; Nobili, B.; Perrotta, S.; et al. The endovanilloid/endocannabinoid system in human osteoclasts: Possible involvement in bone formation and resorption. Bone 2009, 44, 476-484. [CrossRef] [PubMed]

25. Pan, L.; Song, K.; Hu, F.; Sun, W.; Lee, I. Nitric oxide induces apoptosis associated with TRPV1 channel-mediated $\mathrm{Ca}^{2+}$ entry via S-nitrosylation in osteoblasts. Eur. J. Pharmacol. 2013, 715, 280-285. [CrossRef]

26. Kelly, S.; Chapman, R.J.; Woodhams, S.; Sagar, D.R.; Turner, J.; Burston, J.J.; Bullock, C.; Paton, K.; Huang, J.; Wong, A.; et al. Increased function of pronociceptive TRPV1 at the level of the joint in a rat model of osteoarthritis pain. Ann. Rheum. Dis. 2015, 74, 252-259. [CrossRef]

27. Fernihough, J.; Gentry, C.; Bevan, S.; Winter, J. Regulation of calcitonin gene-related peptide and TRPV1 in a rat model of osteoarthritis. Neurosci. Lett. 2005, 388, 75-80. [CrossRef]

28. Barton, N.J.; McQueen, D.S.; Thomson, D.; Gauldie, S.D.; Wilson, A.W.; Salter, D.M.; Chessell, I.P. Attenuation of experimental arthritis in TRPV1R knockout mice. Exp. Mol. Pathol. 2006, 81, 166-170. [CrossRef]

29. Szabó, Á.; Helyes, Z.; Sandor, K.; Bite, A.; Pinter, E.; Nemeth, J.; Bánvölgyi, A.; Bölcskei, K.; Elekes, K.; Szolcsányi, J. Role of transient receptor potential vanilloid 1 receptors in adjuvant-induced chronic arthritis: In vivo study using gene-deficient mice. J. Pharmacol. Exp. Ther. 2005, 314, 111-119. [CrossRef]

30. Ahmed, M.; Bjurholm, A.; Srinivasan, G.R.; Lundeberg, T.; Theodorsson, E.; Schultzberg, M.; Kreicbergs, A. Capsaicin effects on substance P and CGRP in rat adjuvant arthritis. Regul. Pept. 1995, 55, 85-102. [CrossRef]

31. Iadarola, M.J.; Sapio, M.R.; Raithel, S.J.; Mannes, A.J.; Brown, D.C. Long-term pain relief in canine osteoarthritis by a single intra-articular injection of resiniferatoxin, a potent TRPV1 agonist. Pain 2018, 159, 2105-2114. [CrossRef] [PubMed]

32. Cathcart, C.J.; Johnston, S.A.; Reynolds, L.R.; Al-Nadaf, S.; Budsberg, S.C. Efficacy of ABT-116, an antagonist of transient receptor potential vanilloid type 1 , in providing analgesia for dogs with chemically induced synovitis. Am. J. Vet. Res. 2012, 73, 19-26. [CrossRef] [PubMed]

33. Round, P.; Priestley, A.; Robinson, J. An investigation of the safety and pharmacokinetics of the novel TRPV1 antagonist XEN-D0501 in healthy subjects. Br. J. Clin. Pharmacol. 2011, 72, 921-931. [CrossRef] [PubMed]

34. Da Cunha, A.F.; Stokes, A.M.; Chirgwin, S.; Pettifer, G.; Moore, R.M. Quantitative expression of the TRPV-1 gene in central and peripheral nervous tissue in horses. Int. J. Appl. Res. Vet. Med. 2008, 6, 15-23.

35. Yaksh, T.L. The Pain State Arising From the Laminitic Horse: Insights Into Future Analgesic Therapies. J. Equine Vet. Sci. 2010, 30, 79-82. [CrossRef]

36. Brama, P.A.J.; TeKoppele, J.M.; Beekman, B.; Van Weeren, P.R.; Barneveld, A. Matrix metalloproteinase activity in equine synovial fluid: Influence of age, osteoarthritis, and osteochondrosis. Ann. Rheum. Dis. 1998, 57, 697-699. [CrossRef]

37. McIlwraith, C.W. Synovial fluid analysis in the diagnosis of equine joint disease. Equine Pract. 1980, $2,44-48$.

38. Trotter, G.W.; McIlwraith, C.W. Clinical features and diagnosis of equine joint disease. In Joint Disease in the Horse; Mcllwraith, C.W., Trotter, G.W., Eds.; WB Saunders: Philadelphia, PA, USA, 1996; pp. 120-145.

39. Bertone, A.L. Infectious Arthritis. In Joint Disease in the Horse; McIlwraith, C.W., Trotter, G.W., Eds.; WB Saunders: Philadelphia, PA, USA, 1996; pp. 397-409.

40. Smith, A.D.; Morton, A.J.; Winter, M.D.; Colahan, P.T.; Ghivizzani, S.; Brown, M.P.; Hernandez, J.A.; Nickerson, D.M. Magnetic Resonance Imaging Scoring of an Experimental Model of Post-Traumatic Osteoarthritis in the Equine Carpus. Vet. Radiol. Ultrasound 2016, 57, 502-514. [CrossRef]

41. McIlwraith, C.W.; Frisbie, D.D.; Kawcak, C.E.; Fuller, C.J.; Hurtig, M.; Cruz, A. The OARSI histopathology initiative-Recommendations for histological assessments of osteoarthritis in the horse. Osteoarthr. Cartil. 2010, 18, S93-S105. [CrossRef]

42. Haneda, S.; Nagaoka, K.; Nambo, Y.; Kikuchi, M.; Nakano, Y.; Matsui, M.; Miyake, Y.; Macleod, J.N.; Imakawa, K. Interleukin-1 receptor antagonist expression in the equine endometrium during the peri-implantation period. Domest. Anim. Endocrinol. 2009, 36, 209-218. [CrossRef] 
43. Iqbal, J.; Bird, J.L.; Hollander, A.P.; Bayliss, M.T. Effect of matrix depleting agents on the expression of chondrocyte metabolism by equine chondrocytes. Res. Vet. Sci. 2004, 77, 249-256. [CrossRef] [PubMed]

44. GraphPad Prism, Version 8; GraphPad Software: La Joalla, CA, USA, 2018.

45. Calzetta, L.; Rogliani, P.; Pistocchini, E.; Mattei, M.; Cito, G.; Alfonsi, P.; Page, C.; Matera, M.G. Effect of lipopolysaccharide on the responsiveness of equine bronchial tissue. Pulmon. Pharmacol. 2018, 49, 88-94. [CrossRef] [PubMed]

46. Warnock, J.J.; Baltzer, W.I.; Duesterdieck-Zellmer, K.; Ott, J. Minimally invasive synovium harvest for potential use in meniscal tissue engineering. Res. Vet. Sci. 2012, 93, 1472-1480. [CrossRef]

47. Olive, J.; D'anjou, M.A.; Alexander, K.; Laverty, S.; Theoret, C. Comparison of Magnetic Resonance Imaging, Computed Tomography, and Radiography for Assessment of Noncartilaginous Changes in Equine Metacarpophalangeal Osteoarthritis. Vet. Radiol. Ultrasound. 2010, 51, 267-279. [CrossRef]

48. Olive, J.; D'anjou, M.A.; Girard, C.; Laverty, S.; Theoret, C.L. Imaging and histological features of central subchondral osteophytes in racehorses with metacarpophalangeal joint osteoarthritis. Equine Vet. J. 2009, 41, 859-864. [CrossRef]

49. Dyson, S.; Nagy, A.; Murray, R. Clinical and diagnostic imaging findings in horses with subchondral bone trauma of the sagittal groove of the proximal phalanx. Vet. Radiol. Ultrasound 2011, 52, 596-604. [CrossRef]

50. D'anjou, M.A.; Moreau, M.; Troncy, E.; Martel-Pelletier, J.; Abram, F.; Raynauld, J.P.; Pelletier, J.P. Osteophytosis, Subchondral Bone Sclerosis, Joint Effusion and Soft Tissue Thickening in Canine Experimental Stifle Osteoarthritis: Comparison Between 1.5 T Magnetic Resonance Imaging and Computed Radiography. Vet. Surg. 2008, 37, 166-177. [CrossRef]

51. Gonzalez, L.M.; Schramme, M.C.; Robertson, I.D.; Thrall, D.E.; Redding, R.W. MRI Features of Metacarpo(tarso)phalangeal Region Lameness in 40 Horses. Vet. Radiol. Ultrasound 2010, 51, 404-414. [CrossRef]

52. King, J.N.; Zubrod, C.J.; Schneider, R.K.; Sampson, S.N.; Roberts, G. MRI Findings in Horses With Lameness Localized to the Metacarpo(tarso)phalangeal Region and Without a Radiographic Diagnosis. Vet. Radiol. Ultrasound 2013, 54, 36-47. [CrossRef]

53. Powell, S.E. Low-field standing magnetic resonance imaging findings of the metacarpo/metatarsophalangeal joint of racing Thoroughbreds with lameness localised to the region: A retrospective study of 131 horses. Equine Vet. J. 2012, 44, 169-177. [CrossRef]

54. Zubrod, C.J.; Schneider, R.K.; Tucker, R.L.; Gavin, P.R.; Ragle, C.A.; Farnsworth, K.D. Use of magnetic resonance imaging for identifying subchondral bone damage in horses: 11 cases (1999-2003). J. Am. Vet. Med. Assoc. 2004, 224, 411-418. [CrossRef] [PubMed]

55. Peterfy, C.G.; Guermazi, A.; Zaim, S.; Tirman PF, J.; Miaux, Y.; White, D.; Kothari, M.; Lu, Y.; Fye, K.; Zhao, S.; et al. Whole-Organ Magnetic Resonance Imaging Score (WORMS) of the knee in osteoarthritis. Osteoarthr. Cartil. 2004, 12, 177-190. [CrossRef] [PubMed]

56. Bautista, D.M. Spicy science: David Julius and the discovery of temperature- sensitive TRP channels. Temperature 2015, 2, 135-141. [CrossRef] [PubMed]

(C) 2020 by the authors. Licensee MDPI, Basel, Switzerland. This article is an open access article distributed under the terms and conditions of the Creative Commons Attribution (CC BY) license (http://creativecommons.org/licenses/by/4.0/). 